\title{
A SIALIC-ACID-SPECIFIC LECTIN FROM $C E P A E A$ HORTENSIS THAT PROMOTES PHAGOCYTOSIS OF A GROUP-B, TYPE-Ia, STREPTOCOCCAL STRAIN
}

\section{S. E. Holm, Ann-Marie Bergholm, Barbara Wagner* and M. Wagner*}

Institute of Clinical Bacteriology, University of Umeå, S-90185 Umeå, Sweden, and

* Academy of Sciences of the GDR, Research Centre for Molecular Biology and Medicine, Central Institute of Microbiology and Experimental Therapy, DDR-6900 Jena, German Democratic Republic

\begin{abstract}
Summary. Group-B streptococci that possess a type-specific surface polysaccharide undergo phagocytosis only in the presence of antibodies to this, and complement. The snail Cepaea hortensis forms a lectin that is specific for sialic acid; treatment with this promoted the phagocytosis of a group-B streptococcus of serotype Ia (strain O90) in the absence of opsonic antibodies. The effect of the lectin was dose-dependent and required the presence of complement. The specificity of the lectin reaction for sialic acid was proved by the inhibition of phagocytosis by bovine submaxillary mucin. The participation of complement in the reaction was confirmed by demonstrating that $\mathrm{C} 3$ was bound to the surface of lectin-treated cells.
\end{abstract}

\section{INTRODUCTION}

Capsular or surface polysaccharide antigens are important for the virulence of many bacteria (Wright 1927; Kerby 1950; Robbins et al., 1974; Weller et al., 1977; Weinstein and Young, 1978). Sialic acid is present in various types of such polysaccharides (Barry and Goebel, 1957; Liu et al., 1977; Bhattacharjee et al., 1975; Troy, 1979) and seems to have a central role in the resistance of these bacteria to opsonophagocytosis (Robbins et al., 1974; Stevens et al., 1980). Sialic acid is an integrated component of all of the type-specific polysaccharides of the group-B streptococci (GBS) in their "native" form (Baker and Kasper, 1976) and occupies a terminal position on the polysaccharide chain (Jennings et al., 1980, 1983a and $b$ ). As demonstrated by Edwards et al. (1980), the native capsular polysaccharide of type-III GBS inhibits alternative-pathway-mediated opsonophagocytosis by sera that are deficient in type-specific antibodies. If the sialic acid is altered by reduction of the carboxylate group, or is removed by neuraminidase treatment, GBS of type III activate complement through the alternative pathway (Edwards et al., 1982).

Recently we found that the sialic acid-specific lectin from the snail Cepaea hortensis agglutinated all group-B streptococcal strains containing a type-specific polysacchar- 
ide (Wagner, 1982; Wagner et al., 1982) whereas GBS lacking a type-specific polysaccharide, as well as strains of other streptococcal groups and many other bacteria, including species containing sialic acid, were not agglutinated. This finding prompted us to enquire whether binding of this lectin to the type-polysaccharide of GBS modifies the biological function of the capsular material so that phagocytosis is promoted.

\section{MATERIALS AND METHODS}

\section{Bacteria}

The prototype Ia strain of GBS (no. O90, originally obtained from R.C. Lancefield) was used in the main experiments. Other reference type strains used in the agglutination experiments were: type Ib (no. H36B, Lancefield), type Ic (no. A909, Lancefield), type II (no. 18RS21, Lancefield) and type III (no. 6313, Jelinková). The control strain for the phagocytosis experiments was a fresh isolate of Staphylococcus epidermidis (strain S462) (van Furth et al., 1978).

\section{Lectin from Cepaea hortensis}

The lectin was extracted from the lyophilised albumen glands of the snails with $0 \cdot 15 \mathrm{M}$ phosphate-buffered saline, $p \mathrm{H} 7 \cdot 2,1 \mathrm{~g} / 10 \mathrm{ml}$, at $4^{\circ} \mathrm{C}$ overnight (Wagner, 1982). The supernate was absorbed with packed group-C streptococcal cells (strain $\mathrm{H} 46 \mathrm{~A}$ ) for $1 \mathrm{~h}$ at $37^{\circ} \mathrm{C}$, followed by $4 \mathrm{C}$ overnight, to remove a contaminating lectin with a different specificity. Further purification was performed by gel chromatography on Sephadex G-100 (Pharmacia, Uppsala, Sweden). The lectin-containing fractions were pooled, dialysed against distilled water and lyophilised. The agglutination titres of a $1 \%$ lectin solution were 64 against a $5 \%$ human $\mathrm{RBC}$ suspension $(\mathrm{v} / \mathrm{v})$ and four against a GBS type-Ia suspension.

\section{Sialic-acid determination}

The amount of sialic acid in GBS strains before and after treatment with neuraminidase was determined by making extracts in $0 \cdot 1 \mathrm{M}$ hydrochloric acid at $100^{\circ} \mathrm{C}$ and testing these by the thiobarbiturate method (Aminoff, 1961). Suspensions of lyophilised bacteria in $0.1 \mathrm{M}$ sodium-acetate buffer, $p \mathrm{H} 5 \cdot 5$, were incubated with different amounts of neuraminidase either from Vibrio cholerae $(5.5 \mathrm{IU} / \mathrm{mg} ; 0.02 \mathrm{mg} / \mathrm{ml}$, SERVA, Heidelberg) or from Clostridium perfringens (1 IU/mg; $1 \mathrm{mg} / \mathrm{ml}$, Boehringer, Mannheim) for $3 \mathrm{~h}$ at $37^{\circ} \mathrm{C}$. After washing, the cells were either checked by agglutination with $1 \%$ Cepaea lectin or used for determination of the remaining sialic acid as described above.

\section{Phagocytosis experiments}

Basic procedure. The bacterial strains were grown in TY medium (Holm and Falsen, 1967) for $18 \mathrm{~h}$ at $37^{\circ} \mathrm{C}$, washed with $0.15 \mathrm{~m}$ phosphate-buffered saline, $p \mathrm{H} 7 \cdot 2$, and resuspended in the same buffer at $1 \times 10^{7} \mathrm{cfu} / \mathrm{ml}$. Phagocytosis was performed by the method of van Furth et al. (1978) as modified slightly by Löfgren et al. (1983). Briefly, human polymorphonuclear (PMN) cells were prepared by dextran sedimentation followed by lysis of the remaining erythrocytes. The PMN cells were suspended in RPMI-HEPES medium (Gibco Ltd, Paisley, Scotland) to a concentration of $10^{7}$ cells $/ \mathrm{ml}$ from which $0 \cdot 1 \mathrm{ml}$ was used in each reaction. The PMN cells were mixed at $0^{\circ} \mathrm{C}$ with $0.1 \mathrm{ml}$ of bacterial suspension, and $0.1 \mathrm{ml}$ of human or guinea-pig serum was added as a source of complement, and $0.05 \mathrm{ml}$ of $\mathrm{Mg}^{2+} / \mathrm{Ca}^{2+}$ buffer $(1.0 \mathrm{~mm}$ and $3.15 \mathrm{~mm}$, respectively) solution. In a control, the serum was inactivated by heating for $30 \mathrm{~min}$ at $56^{\circ} \mathrm{C}$. The final reagent mixture was adjusted to $0.5 \mathrm{ml}$ by addition of the RPMI-HEPES medium and then incubated at $37^{\circ} \mathrm{C}$ under slow rotation $(60 \mathrm{rpm})$. Samples were drawn from the tubes at time 0 and $60 \mathrm{~min}$ and cfu determinations were performed before and after centrifugation at $110 \mathrm{~g}$ for $10 \mathrm{~min}$ at $4^{\circ} \mathrm{C}$. The supernates were diluted in ice-cold phosphate-buffered saline and viable 
bacteria were counted by plating on blood-agar plates. As recommended by van Furth et al. (1978), the activity of the PMNs was controlled by the use of a strain of $S$. epidermidis; only when this control showed a decrease of $1 \cdot 5-2 \cdot 0 \log _{10} \mathrm{cfu}$, were the PMN cells used for the experiment with the lectin.

Antiserum-treated GBS. In some of the experiments an equal amount of the medium was replaced by $0.075 \mathrm{ml}$ of an antiserum against GBS type IA (Wagner et al., in press).

Neuraminidase-treated $G B S$. In the phagocytosis experiments the GBS strain was treated with neuraminidase $(V$. cholerae $1 \mathrm{IU} / \mathrm{ml})$ in a proportion of $0.2 \mathrm{ml} \mathrm{GBS}$ suspension in $0.15 \mathrm{ml}$ of neuraminidase. After incubation for $30 \mathrm{~min}$ at $37^{\circ} \mathrm{C}$ the bacteria were washed twice in PBS.

Lectin-treated GBS. The Cepaea lectin was used at final concentrations of $1 \cdot 5 \%-0 \cdot 15 \%$ in the reaction tubes. For counting viable bacteria after phagocytosis, the cell suspensions as well as the supernates were treated sonically for $4 \mathrm{~s}$ (MSE Instruments, $8 \mu \mathrm{m}, 60 \mathrm{~W}$ ) to break clumps of agglutinated bacteria before plating. The sialic-acid specificity of the lectin was checked by its inhibition by bovine submaxillary mucin (Sigma). In this experiment $75 \mu \mathrm{l}$ of the medium was replaced by a mucin solution ( $25 \mathrm{mg}$ of mucin $/ \mathrm{ml}$ of distilled water).

The results of all phagocytosis experiments were expressed as the decrease of the original cfu of the GBS suspension ( $1 \log _{10}$ decrease equals $90 \%$ phagocytosis, $2 \log _{10}$ equals $99 \%$ phagocytosis).

\section{Immunofluorescent detection of bound $\mathrm{C} 3$ on streptococci}

Suspensions of GBS type-Ia cells untreated or treated with neuraminidase or Cepaea lectin were incubated in the presence of fresh or heat-inactivated $\left(30 \mathrm{~min}\right.$ at $\left.56^{\circ} \mathrm{C}\right)$ human serum for $1 \mathrm{~h}$ at $37^{\circ} \mathrm{C}$. The suspensions were washed, and the sediments were spread and fixed on glass slides and finally incubated with FITC-labelled anti-human C3d (Behringwerke, Germany) for $30 \mathrm{~min}$ at $20^{\circ} \mathrm{C}$. The slides were washed and examined with a Leitz Fluoropan microscope.

\section{RESULTS}

\section{Determination of sialic acid in GBS and its removal by neuraminidase}

We first established the efficacy of the hydrochloric-acid procedure for the extraction of sialic acid from the GBS type-Ia strain O90. Acid extracts of various amounts of dried bacteria were analysed for sialic acid by the thiobarbituric-acid method. The proportion of extracted sialic acid to the dry weight of bacteria was similar (table I), indicating the same degree of extraction over a wide range of bacterial weights (2-9 mg dry weight).

The capacity of various amounts of $V$. cholerae neuraminidase to remove the sialic acid from $9 \mathrm{mg}$ dry weight of strain 090 was then measured. Treatment with $2 \mu \mathrm{g}$ of $V$. cholerae neuraminidase resulted in a complete removal of sialic acid (table II). The

TABLE I

Quantative estimation of sialic acid in hydrochloric-acid extracts of group-B streptococci (type 1a, strain 090$)$ in relation to bacterial weight

\begin{tabular}{ccc}
\hline $\begin{array}{c}\text { Dry weight } \\
\text { (mg) of bacteria } \\
\text { extracted }\end{array}$ & $\begin{array}{c}\text { Sialic acid } \\
\text { content } \\
(\mu \mathrm{g})\end{array}$ & $\begin{array}{c}\text { Ratio }(\%) \\
\text { sialic acid/ } \\
\text { bacterial weight }\end{array}$ \\
\hline 9.0 & 31.4 & 0.35 \\
4.5 & 14.6 & 0.32 \\
2.3 & 7.5 & 0.33 \\
\hline
\end{tabular}


TABLE II

Amount of sialic acid remaining in GBS cells (strain O90)* after treatment with $V$. cholerae neuraminidase

\begin{tabular}{lc}
\hline $\begin{array}{c}\text { Enzyme } \\
(\mu \mathrm{g})\end{array}$ & $\begin{array}{c}\text { Remaining } \\
\text { sialic acid } \\
(\mu \mathrm{g})\end{array}$ \\
\hline 0 & 31.4 \\
0.12 & 8.4 \\
0.25 & 7.4 \\
0.50 & 5.4 \\
1.0 & 3.2 \\
2.0 & 0
\end{tabular}

* Dry weight of bacteria: $9 \mathrm{mg}$.

TABLE III

Variation in neuraminidase sensitivity in GBS type strains, as estimated by agglutination with Cepaea hortensis lectin

\begin{tabular}{|c|c|c|c|c|}
\hline \multirow[b]{3}{*}{ Type } & \multirow[b]{3}{*}{ Strain no. } & \multicolumn{3}{|c|}{ Strength of agglutination of } \\
\hline & & \multirow{2}{*}{$\begin{array}{l}\text { untreated } \\
\text { cells }\end{array}$} & \multicolumn{2}{|c|}{$\begin{array}{l}\text { cells treated with } \\
\text { neuraminidase from }\end{array}$} \\
\hline & & & $V$. cholerae & C. perfringens \\
\hline Ia & O90 & $++t$ & - & - \\
\hline $\mathrm{Ib}$ & $\mathrm{H} 36 \mathrm{~B}$ & +++ & + & ++ \\
\hline Ic & A909 & $++t$ & + & $(+)$ \\
\hline $\begin{array}{l}\text { II } \\
\text { III }\end{array}$ & $\begin{array}{l}\text { 18RS2I } \\
6313\end{array}$ & $\begin{array}{l}+++ \\
+++\end{array}$ & $\begin{array}{l}++ \\
(+)\end{array}$ & $(+)$ \\
\hline
\end{tabular}

,,,$++++++(+)=$ arbitrary estimates of the strength of agglutination; $-=$ no agglutination.

removal by the enzyme was dose-related, and as little as $0 \cdot 12 \mu \mathrm{g}$ of enzyme released about three-quarters of the sialic acid. Controls of agglutinability of this strain by the Cepaea lectin at various stages of enzymatic treatment revealed that only preparations completely lacking detectable amounts of sialic acid were inagglutinable. These experiments were extended to all five reference GBS type-strains to compare the enzymatic removal of sialic acid by neuraminidases from two different sources. After treatment with either of the two enzymes (table III) only the type-Ia strain failed to be agglutinated by the sialic-acid-specific lectin, while the other strains were still agglutinable to a variable degree. Examination of other GBS strains from all types (see Materials and methods) showed a variability of between 15 and $63 \%$ in the amount of sialic acid remaining after treatment of $9 \mathrm{mg}$ of bacteria with $1 \mu \mathrm{g}$ of $V$. cholerae neuraminidase. There was no correlation between the neuraminidase sensitivity and the serotype of GBS.

\section{Phagocytosis experiments}

The results of the phagocytosis experiments with strain O90 of GBS type Ia are 
summarised in table IV. No decrease of viable GBS was demonstrable in the absence of PMN cells (experiments a-e). Other controls showed an absence of significant phagocytosis of GBS that had not been treated with neuraminidase, both in the presence (experiment $f$ ) and the absence (experiment $g$ ) of complement; on the other hand, cells that had been treated with neuraminidase to remove the sialic acid underwent phagocytosis (experiment $h$ ), but only in the presence of complement (experiment i).

Cepaea hortensis lectin promoted a dose-dependent phagocytosis in the presence of complement (experiments $j-m$ ). The significance of complement for the lectin-promoted phagocytosis is illustrated in experiments $n$ and $o$. This effect was abolished by the addition of bovine submaxillary mucin to the reaction mixture (experiment $p$ ).

TABLE IV

Influence of Cepaea hortensis lectin on phagocytosis of GBS (type Ia, strain O60)

\begin{tabular}{|c|c|c|c|c|c|c|c|}
\hline \multirow[b]{2}{*}{ Experiment } & \multicolumn{5}{|c|}{ Components in the reaction mixture } & \multirow[b]{2}{*}{$\begin{array}{l}\text { Number of } \\
\text { experiments }\end{array}$} & \multirow{2}{*}{$\begin{array}{l}\text { Mean } \\
\text { decrease in } \\
\text { counts* } \\
\left(\log _{10}\right)\end{array}$} \\
\hline & $\begin{array}{l}\text { PMN } \\
\text { cells }\end{array}$ & Complement & $\begin{array}{c}\text { Neuraminidase- } \\
\text { treated GBS }\end{array}$ & $\begin{array}{c}\text { Cepaea lectin } \\
(\%)\end{array}$ & Mucin & & \\
\hline a & - & - & - & - & - & 2 & 0 \\
\hline b & - & + & - & - & - & 2 & 0 \\
\hline $\mathrm{c}$ & - & + & _ & 1.5 & - & 2 & 0 \\
\hline d & - & - & - & 1.5 & - & 1 & 0 \\
\hline $\mathrm{e}$ & - & + & + & - & - & $i$ & 0 \\
\hline $\mathrm{f}$ & + & + & - & - & - & 4 & 0.2 \\
\hline $\mathrm{g}$ & + & - & - & - & - & 1 & 0.2 \\
\hline h & + & + & + & - & - & 2 & 1.6 \\
\hline $\mathrm{i}$ & + & - & + & - & - & 1 & $0 \cdot 3$ \\
\hline $\mathrm{j}$ & + & + & - & 1.5 & - & 2 & 1.6 \\
\hline $\mathrm{k}$ & + & + & - & 0.75 & - & 2 & 1.5 \\
\hline 1 & + & + & - & 0.3 & - & 4 & 1.2 \\
\hline $\mathrm{m}$ & + & + & - & $0 \cdot 15$ & - & 2 & 0.8 \\
\hline $\mathrm{n}$ & + & - & - & 1.5 & - & 4 & $0 \cdot 1$ \\
\hline 0 & + & $\dagger$ & - & 1.5 & - & 1 & 0 \\
\hline $\mathrm{p}$ & + & + & - & 1.5 & + & 1 & 0 \\
\hline
\end{tabular}

$+=$ Component present $--=$ component absent.

* Duplicate counts in each experiment.

$\dagger$ Heat-inactivated serum present.

In another experiment (not shown in table III) we confirmed that, when anti-type-Ia serum was added to a reaction mixture of untreated type-Ia GBS and complement, there was good phagocytosis $\left(1.9 \log _{10}\right.$ decrease in count).

\section{Binding of C3d to GBS type Ia}

Suspensions of GBS type-Ia bacteria (strain O90), either untreated or after treatment with lectin or neuraminidase, were incubated in the presence of fresh or heated human serum. The addition of FITC-labelled anti-human C3d revealed that only GBS type-Ia cells that had been treated with neuraminidase or lectin and incubated with fresh serum could bind C3d. All other combinations resulted in a negative immunofluorescence test.

\section{Discussion}

Like many other sialic acid-containing bacteria, GBS with a type-specific polysaccharide at the surface cannot be phagocytosed in the absence of opsonic 
antibodies (Lancefield et al., 1975; Baltimore et al., 1977). Edwards et al. (1980) showed in a GBS type-III strain that removal of sialic acid from the type-specific polysaccharide renders the cells susceptible to phagocytosis in the presence of complement only. We have now shown that also blocking of the sialic acid by the sialic acid-specific lectin from Cepaea hortensis (Wagner, 1982) leads to the promotion of phagocytosis of a GBS type-Ia strain. The specificity of this effect was confirmed by its inhibition by bovine submaxilliary mucin. The use of different amounts of the lectin also showed that the phagocytosis-promoting effect of the lectin was dose-dependent. Complement is necessary in this process, because in its absence, or in the presence of inactivated complement, no phagocytosis could be observed. Furthermore, in the presence of the lectin the binding of $\mathrm{C} 3 \mathrm{~d}$ on the bacteria could be demonstrated. We also confirmed that removal of the sialic acid from the GBS type-Ia strain by neuraminidase allows phagocytosis in the presence of complement, as Edwards et al. (1982) had shown for a type-III strain. By agglutination studies with Cepaea lectin and by chemical determination of the remaining sialic acid we could show that in the type Ia-strain the neuraminidases from $V$. cholerae and from $C$. perfringens both remove the total sialic acid content. On the other hand, complete removal could not be obtained by enzymatic treatment of the reference strains of types Ib, Ic, II and III. This is in accordance with the observation of Shigeoka et al. (1978), who noted that differences in phagocytosis between types II and III could probably be referred to differences in their sensitivity to neuraminidase. In the present study we noted that sensitivity to neuraminidase, as revealed by determination of the remaining sialic acid after neuraminidase treatment, varied between strains and not only between types. It had earlier been shown that in the absence of opsonic antibodies the phagocytosis of GBS after removing the sialic acid proceeds through the alternative pathway (Edwards et al., 1982). In the present study, we demonstrated that complement is also necessary for phagocytosis after blocking the sialic acid by the lectin; but so far we have no information about the complement-activation pathway under these conditions.

The skilful technical assistance of Helén Jonsson and the financial support of LEO Research Foundation are highly appreciated.

\section{REFERENCES}

Aminoff D 1961 Methods for the quantitative estimation of N-acetylneuraminic acid and their application to hydrolysates of sialomucoids. Biochemical Journal 81: 384-392.

Baker C J, Kasper D L 1976 Identification of sialic acid in polysaccharide antigens of group B Streptococcus. Infection and Immunity 13: 284-288.

Baltimore R S, Kasper D L, Baker C J, Goroff D K 1977 Antigenic specificity of opsonophagocytic antibodies in rabbit antisera to group B streptococci. Journal of Immunology 118: 673-678.

Barry G T, Goebel W F 1957 Colominic acid, a substance of bacterial origin related to sialic acid. Nature 179: 206.

Bhattacharjee A K, Jennings H J, Kenny C P, Martin A, Smith I C P 1975 Structural determination of the sialic acid polysaccharide antigens of Neisseria meningitidis serogroups $\mathrm{B}$ and $\mathrm{C}$ with carbon 13 nuclear magnetic resonance. Journal of Biological Chemistry 250: $1926-1932$.

Edwards M S, Kasper D L, Jennings H J, Baker C J, Nicholson-Weller A 1982 Capsular sialic acid prevents activation of the alternative complement pathway by type III, group B streptococci. Journal of Immunology 128: 1278-1283. 
Edwards M S, Nicholson-Weller A, Baker C J, Kasper D L 1980 The role of specific antibody in alternative complement pathway-mediated opsonophagocytosis of type III, group B Streptococcus. Journal of Experimental Medicine 151: 1275-1287.

Holm S E, Falsen E 1967 An antigen-free medium for cultivation of beta-hemolytic streptococci. Acta Pathologica et Microbiologica Scandinavica 69: 264-276.

Jennings H J, Katzenellenbogen E, Lugowski C, Kasper D L 1983a Structure of native polysaccharide antigens of type Ia and type Ib group B Streptococcus. Biochemistry 22: $1258-1264$.

Jennings H J, Rosell K-G, Kasper D L 1980 Structural determination and serology of the native polysaccharide antigen of type-III group B Streptococcus. Canadian Journal of Biochemistry 58: 112-120.

Jennings H J, Rosell K-G, Katzenellenbogen E, Kasper D L $1983 b$ Structural determination of the capsular polysaccharide antigen of type II group B Streptococcus. Journal of Biological Chemistry 258: 1793-1798.

Kerby G P 1950 A comparison of the removal of mucoid and non-mucoid variants of Klebsiella pneumoniae type $\mathrm{b}$ from the splanchnic circulating blood of the intact animal. Journal of Immunology 64: 131-137.

Lancefield R C, McCarty M, Everly W N 1975 Multiple mouse-protective antibodies directed against group B streptococci. Special reference to antibodies effective against protein antigens. Journal of Experimental Medicine 142: 165-179.

Liu T Y, Gotschlich E C, Dunne F T, Jonssen E K 1977 Studies on the meningococcal polysaccharides. Composition and chemical properties of the group $\mathrm{B}$ and $\mathrm{C}$ polysaccharide. Journal of Biological Chemistry 246: 4703-4712.

Löfgren S, Tärnvik A, Bloom G D, Sjöberg, W 1983 Phagocytosis and killing of Francisella tularensis by human polymorphonuclear leukocytes. Infection and Immunity 39: 715-720.

Robbins J B, McCracken G H, Gotschlich E C, Orskov F, Orskov I, Hanson L A 1974 Escherichia coli $\mathrm{K} 1$ capsular polysaccharide associated with neonatal meningitis. New England Journal of Medicine 290: 1216-1219.

Shigeoka A O, Hall R T, Hemming V G, Allred C D, Hill H R 1978 Role of antibody and complement in opsonization of group B streptococci. Infection and Immunity 21: 34-40.

Stevens P, Chu C L, Young L S $1980 \mathrm{~K}-1$ antigen content and the presence of an additional sialic acid-containing antigen among bacteremic K-1 Escherichia coli: correlation with susceptibility to opsonophagocytosis. Infection and Immunity 29: 1055-1061.

Troy F A 1979 The chemistry and biosynthesis of selected bacterial capsular polymers. Annual Review of Microbiology 33: 519-560.

van Furth R, van Zwet T L, Leijh P C J 1978 In vitro determination of phagocytosis and intracellular killing by polymorphonuclear and mononuclear phagocytes. In: Weir D M (ed) Handbook of experimental immunology, 3rd edn, Chapter 32. Blackwell Scientific Publications, Oxford.

Wagner M 1982 Agglutination of bacteria by a sialic acid-specific lectin of the snail Cepaea hortensis. Acta histochemica 71: 35-39.

Wagner M, Wagner B, Bergholm A-M, Holm S E Experimental infection with group B streptococci in tissue cages implanted in rabbits. Zentralblatt für Bakteriologie, Parasitenkunde Infektionskrankheiten und Hygiene Abt 1 Orig $\mathrm{A}$, in press.

Wagner M, Wagner B, Günther E 1982 Interaction of a sialic acid-specific lectin of the snail Cepaea hortensis with group B streptococci. In: Holm S E, Christensen P (eds) Basic concepts of streptococci and streptococcal diseases. Reedbooks Ltd, Chertsey, Surrey, pp 70-71.

Weinstein R, Young L S 1978 Phagocytic resistance of Escherichia coli K-1 isolates and relationship to virulence. Journal of Clinical Microbiology 8: 748-755.

Weller P F, Smith A L, Anderson P, Smith D H 1977 The role of encapsulation and host age in the clearance of Haemophilus influenzae bacteremia. Journal of Infectious Diseases 135: 34-40.

Wright H D 1927 Experimental pneumococcal septicaemia and anti-pneumococcal immunity. Journal of Pathology and Bacteriology 30: 185-252. 